\title{
Electron-paramagnetic resonance and infrared spectroscopic research of the structure of a southfield Polyvinylidene difluoride near the percolation threshold
}

\author{
Abdusalam Umarov ${ }^{*}$, Dilnavoz Kamolova ${ }^{2}$, and Makhmudjon Kurbonov ${ }^{3}$ \\ ${ }^{1}$ Tashkent State Transport University, Tashkent, Uzbekistan \\ ${ }^{2}$ Navoi State Pedagogical Institute, Navai, Uzbekistan \\ ${ }^{3}$ Namangan State University, Namangan, Uzbekistan
}

\begin{abstract}
In this paper, the results of scientific research work are carried out to study the role of the interfacial layer in filled polymer materials using infrared and electron-paramagnetic resonance spectroscopy using the fundamentals of solid-state physics. At the same time, the authors of this work used all the rich experience of both experimenters and theoreticians working in this field of science and their own developments regarding methods for controlling the structure of these materials. It is noteworthy that the material interpreted in this work concerns composites subjected to special technological preparation, including the stage of ultrasonic dispersion of filler particles in a binder medium.
\end{abstract}

\section{Introduction}

Various branches of modern technology would benefit from a wide range of non-traditional materials, in most cases rare, expensive, and time-consuming in terms of the nature of the technological preparation. Unconventional materials with controlled properties also include soot-filled composites, the one-sided technological preparation of which, to some extent, inhibits and limits the finding of their application in new areas.

The fruitfulness of this kind of approach to studying the properties of filled polymer materials (FPM) has shown its results. Not only were the structural features of the interphase layer (IFL) revealed in the FPM, but completely new, previously unforeseen properties of these composites were also discovered. For example, almost all soot containing composites of polyvinylidene difluoride (PVDF), despite their compositions of organic origin, exhibit strongly broadened, inhomogeneous, and very stable electronparamagnetic resonance (EPR) signals, which are comparable in width and, in some cases, even exceed similar parameters of some classical "magnets. Serious attempts have been made to explain such enhancements to magnetism. The combination of optical studies of these FPMs opens up new prospects. It gives great hopes associated with the development of recording media from such composites for optical information recording and

*Corresponding author: abdusalom@inbox.ru 
photographic image acquisition, which excludes the stage of chemical-photographic processing with silver halide layers. Based on the strong absorption capacity of fathomfilled composites PVDF infrared (IR) rays, the author has written laboratory technological regulations for new temperature sensors from these composites, replacing semimetals metal glasses in these roles. In general, it should be noted that the use of various configurations of samples from the studied composite and polymer materials will reduce the need for precious metals, reduce the cost of working parts made on their basis for computers, optical and magnetic technology, and expand their scope.

\section{Methods}

The electron paramagnetic resonance (EPR) study was performed on a radio spectrometer of the E-4 model (Varian company). The minimum spin concentration that was available for recording by this device was the value of $10^{11}$ spins. Improving the resolution often leads to a deterioration in the sensitivity to get a gain in resolution and vice versa. To determine the area under the absorption curves, the modulation amplitude was selected as follows:

$$
H_{m}-(2-4) H_{P P \max }
$$

Where: $\mathrm{H}_{\mathrm{PPmax}}$ is the maximum signal width depending on the power of the microwave field.

The experimental conditions were chosen when neither the standard nor the sample was saturated, and the test and standard samples were at the same temperature. The concentration of paramagnetic centers (p. m. c.) was determined by the graphical method of integration by amplitudes and areas, and was calculated by comparison with reference samples ( $\alpha, \alpha$ diphenyl, $\beta$ picrylhydrazyl) (DPPG) according to the following formula:

$$
N_{\chi}=\frac{N_{a}}{m_{\chi}} \frac{s_{\chi}}{S_{a}}
$$

Where: $\mathrm{N}_{\mathrm{a}}$ is the concentration of the standard spins (spin / g);

$\mathrm{m}_{\chi}$ is the mass of the test substance ( $\mathrm{spin} / \mathrm{g}$ );

$\mathrm{S}_{\chi}, \mathrm{S}_{\mathrm{a}}$ is the area under the curved sample and the reference, respectively

The error in calculating the concentration of p.m.c. is $20-30 \%$. The value of the line width $\mathrm{H}_{\mathrm{PP}}$ was calculated directly from the sheets calibrated by the scan scale.

Calculation of the values of the $\mathrm{g}$ factors manufacturers by the formula:

$$
g=g_{a}+g_{a} \frac{-\left(H_{\chi}-H_{a}\right)}{H_{a}}
$$

Where: $\mathrm{g}_{\mathrm{a}}$ is the reference factor, i.e., DPPG;

$\mathrm{h}_{\chi}$ is resonant magnetic field of the sample;

$\mathrm{H}_{\mathrm{a}}$ is the resonant magnetic field of the reference.

The saturation factor is determined by the formula:

$$
S=Z^{2}=\left(\frac{I_{X} / I_{a}}{Z_{a}}\right)^{2}
$$

Where: $i_{\chi}, I_{a}$ is the signal intensity of the reference sample at a given power $(\mathrm{W}, \mathrm{mBr})$ MICROWAVE fields; 


$$
Z_{a}=\frac{\left(I_{\chi}\right)_{0}}{\left(I_{a}\right)_{0}}
$$

Where: $\left(i_{x}\right)_{0},\left(I_{a}\right)_{0}$ the intensity of the EPR signals of the reference sample at zero power.

IR spectra of film carbon black-filled samples of polyvinylidene fluoride (PVDF) were recorded on Specord 75 IR spectrometers (manufactured by the GDR) IR spectra of soot powders were recorded in a compressed $\mathrm{KVg}$ tablet. The experimental conditions were room temperature and the following instrument data: gain-5, gap-3, filter-10, recording time-44 minutes. UV and VD spectra were captured on SF-46.

\section{Results and Discussion}

In this paper, an attempt is made to elucidate the role of interfacial layers (IFL) in composites based on polyvinylidene fluoride (PVDF) filled with soot near the percolation threshold $\left(\mathrm{v}_{\mathrm{i}}=0.04<0.051=\mathrm{v}_{\mathrm{c}}\right)$ prepared by ultrasonic dispersion using analysis of its molecular vibrations and paramagnetic characteristics.

The vibrational spectra of the composite studied in the mid-infrared (IR) range are shown in Figure 1. The spectrum shown in this figure is uninformative due to the very weak sparseness of the bands and the strong absorbability of the composite. However, the absorption bands selected for analysis characterize the structural features of the composite since they have repeatability in a series of experiments. On the whole, the IR spectrum of the composite has in mind the strong absorption capacity of these materials in a wide range of medium IR wavelengths $\left(4000-1400 \mathrm{~cm}^{-1}\right)$ and the increase in transmittance when approaching the far-infrared region.

In general, the following absorption bands of the composite may be the subject of discussion - 3868; 3452; 3000; 2850; 2800; 1430; 1358; 1181; 728; 523.5 and $429.3 \mathrm{~cm}^{-1}$. As a first approximation, it would be convenient to attribute the bands revealed for the composite in the region of $4000-400 \mathrm{~cm}^{-1}$ wavelengths to various groups (carboxyl, quinone, phenolic, lactone, etc.) that are possibly available, as was established in [1], which we used in the work of soot brand DG-100. However, a more rigorous approach to the interpretation and attribution of these bands may show something else. Thus, according to Rabek Ya. [2], bands in the range 4000-400 $\mathrm{cm}^{-1}$ can touch not only various compounds based on carbon-oxygen or oxygen-hydrogen bonds but also compounds with a sulfuroxygen bond. In our case, compounds with a sulfur-oxygen bond may occur due to incomplete volatilization of the solvent in the form of dimethyl sulfoxide (DMSO) from the composite. A detailed analysis of the comparative nature of the composite bands with vibrational spectra of compounds known from [2-4] based on fluorinated unsaturated (Table 1) and paraffin (Table 2) hydrocarbons, as well as on some fluorinated benzene (Table 3), shows the more or less satisfactory result with compounds such as three fluoroethylene, methyl fluoride, meta- and para-difluorobenzene. Most of the other bands, even for these compounds, do not coincide with the bands of the composite. One of the possible reasons for this can be as follows. 
Table 1. Vibrational spectra of fluorinated unsaturated hydrocarbons

\begin{tabular}{|l|l|l|l|l|l|}
\hline \multicolumn{2}{|l|}{$\mathrm{CH}_{3} \mathrm{~F}$ methyl fluoride } & \multicolumn{3}{l|}{$\begin{array}{l}\mathrm{C}_{2} \mathrm{HF} \\
\text { monofluoroacetylene }\end{array}$} & \multicolumn{2}{l|}{$\begin{array}{l}\text { 的 } \mathrm{F}_{4} \\
\text { tetrafluoroethylene }\end{array}$} \\
\hline $\begin{array}{l}\text { Form. } \\
\text { Fluctuations }\end{array}$ & $v, \mathrm{sm}^{-1}$ & $\begin{array}{l}\text { Form. } \\
\text { fluctuations }\end{array}$ & $v, \mathrm{sm}^{-1}$ & $\begin{array}{l}\text { Form. } \\
\text { fluctuations }\end{array}$ & $v, \mathrm{sm}^{-1}$ \\
\hline $\mathrm{q}(\mathrm{CH})$ & 3006 & $\mathrm{q}(\mathrm{CH})$ & 3355 & $\mathrm{Q}(\mathrm{C}-\mathrm{F})$ & 1337 \\
\hline $\mathrm{q}(\mathrm{CH})$ & 2964.5 & $\mathrm{Q}(\mathrm{C} \equiv \mathrm{C})$ & 2255 & $\mathrm{Q}(\mathrm{C}-\mathrm{F})$ & 1186 \\
\hline$\alpha(\mathrm{HCH})$ & 1466.5 & $\mathrm{Q}(\mathrm{C}-\mathrm{F})$ & 1055 & $(\mathrm{FCF})$ & 558 \\
\hline$\alpha(\mathrm{HCH})$ & 1464 & $\beta(\mathrm{C} \equiv \mathrm{C}-\mathrm{H})$ & 578 & $\left(\mathrm{CF}_{2}\right)$ & 406 \\
\hline$\delta(\mathrm{HCF})$ & 1182.3 & $v(\mathrm{C} \equiv \mathrm{C}-\mathrm{F})$ & 367 & $v(\mathrm{CCF})$ & 218 \\
\hline $\mathrm{Q}(\mathrm{CF})$ & 1048.6 & & & & \\
\hline
\end{tabular}

Table 1 continued

\begin{tabular}{|c|c|c|c|}
\hline \multicolumn{2}{|c|}{$1,1 \mathrm{C}_{2} \mathrm{H}_{2} \mathrm{~F}_{2} 1,1$ difluoroethylene } & \multicolumn{2}{|c|}{$\mathrm{C}_{2} \mathrm{H}_{3} \mathrm{~F}_{2}$ cis difluoroethylene } \\
\hline Form. Fluctuations & $v, \mathrm{sm}^{-1}$ & Form. Fluctuations & $v$, sm $^{-1}$ \\
\hline $\mathrm{q}(\mathrm{CH})$ & 3103 & $\mathrm{q}(\mathrm{CH})$ & 3135 \\
\hline $\mathrm{q}(\mathrm{CH})$ & 3060 & $\mathrm{q}(\mathrm{CH})$ & 3135 \\
\hline $\mathrm{Q}(\mathrm{C}=\mathrm{C})$ & 1728 & $\mathrm{Q}(\mathrm{C}=\mathrm{C})$ & 1715 \\
\hline$\alpha(\mathrm{HCH})$ & 1414 & $\beta(\mathrm{C} \equiv \mathrm{C}-\mathrm{H})$ & 1376 \\
\hline $\mathrm{Q}(\mathrm{CF})$ & 1302 & $\beta(\mathrm{C} \equiv \mathrm{C}-\mathrm{H})$ & 1266 \\
\hline$\beta(\mathrm{CCH})$ & 955 & $\mathrm{Q}(\mathrm{CF})$ & 1127 \\
\hline $\mathrm{Q}(\mathrm{CF})$ & 926 & $\mathrm{Q}(\mathrm{CF})$ & 1014 \\
\hline$\rho\left(\mathrm{CH}_{2}\right)$ & 803 & $\rho(\mathrm{CHF})$ & 866 \\
\hline$\rho\left(\mathrm{CF}_{2}\right)$ & 611 & $v(\mathrm{CCF})$ & 768 \\
\hline$v(\mathrm{FCF})$ & 550 & $\rho(\mathrm{CHF})$ & 756 \\
\hline$v(\mathrm{CCF})$ & 438 & $\mathrm{X}$ & 482 \\
\hline & & $v(\mathrm{CCF})$ & 255 \\
\hline
\end{tabular}

Table 2.Vibrational spectra of fluorinated paraffinic hydrocarbons

\begin{tabular}{|c|c|c|c|c|c|c|c|}
\hline \multicolumn{2}{|c|}{$\begin{array}{c}\mathrm{C}_{2} \mathrm{~F}_{3} \mathrm{H} \text { three } \\
\text { fluoroethylene }\end{array}$} & \multicolumn{2}{c|}{$\begin{array}{c}\mathrm{CH}_{3}-\mathrm{CF}_{3} 1.1 .1 \text { three } \\
\text { fluoroethane }\end{array}$} & \multicolumn{2}{c|}{$\mathrm{CH}_{2} \mathrm{~F}_{2}$ difluoromethane } & \multicolumn{2}{c|}{$\mathrm{CF}_{3} \mathrm{H}$} \\
\hline $\begin{array}{c}\text { Form. } \\
\text { Fluctuat } \\
\text { ions }\end{array}$ & $v \cdot \mathrm{sm}^{-1}$ & $\begin{array}{c}\text { Form. } \\
\text { fluctuations }\end{array}$ & $v \cdot \mathrm{sm}^{-1}$ & $\begin{array}{c}\text { Form. } \\
\text { fluctuations }\end{array}$ & $v \cdot \mathrm{sm}^{-1}$ & $\begin{array}{c}\text { Form. } \\
\text { Fluctuatio } \\
\text { ns }\end{array}$ & $v \cdot \mathrm{sm}^{-1}$ \\
\hline $\mathrm{q}(\mathrm{CH})$ & 3150 & $\mathrm{q}(\mathrm{C}-\mathrm{H})$ & 3040 & $\mathrm{q}(\mathrm{C}-\mathrm{H})$ & 3015 & $\mathrm{q}(\mathrm{C}-\mathrm{H})$ & 3035 \\
\hline $\mathrm{Q}(\mathrm{C}=\mathrm{C})$ & 1788 & $\mathrm{q}(\mathrm{C}-\mathrm{H})$ & 2974 & $\mathrm{q}(\mathrm{C}-\mathrm{H})$ & 2949 & $\delta(\mathrm{HCF})$ & 1375 \\
\hline $\begin{array}{c}\mathrm{QCF} \\
-\mathrm{F})\end{array}$ & 1362 & $\alpha(\mathrm{HCH})$ & 1450 & $\delta(\mathrm{HCF})$ & 1430 & $\mathrm{Q}(\mathrm{CF})$ & 1152 \\
\hline$\beta(\mathrm{HCF})$ & 1264 & $\mathrm{Q}(\mathrm{CF})$ & 1279 & $\delta(\mathrm{HCF})$ & 1165 & $\gamma(\mathrm{FCF})$ & 699.2 \\
\hline $\mathrm{Q}(\mathrm{C}-\mathrm{F})$ & 1171 & $\mathrm{Q}(\mathrm{CF})$ & 1220 & $\mathrm{Q}(\mathrm{CF})$ & 1090 & $\gamma(\mathrm{FCF})$ & 507.2 \\
\hline $\mathrm{Q}(\mathrm{C}-\mathrm{F})$ & 929 & $\beta(\mathrm{CCH})$ & 968 & $\mathrm{Q}(\mathrm{CF})$ & 1070 & & \\
\hline$\rho(\mathrm{CHF})$ & 750 & $\mathrm{Q}(\mathrm{C}-\mathrm{C})$ & 829 & $\gamma(\mathrm{FCF})$ & 529 & & \\
\hline$\rho(\mathrm{CF})$ & 623 & $\gamma(\mathrm{FCF})$ & 603 & & & & \\
\hline$\gamma(\mathrm{FCF})$ & 555 & $\gamma(\mathrm{FCF})$ & 541 & & & & \\
\hline$\gamma(\mathrm{CCF})$ & 435 & $\gamma(\mathrm{CCF})$ & 358 & & & & \\
\hline $\mathrm{X}$ & 305 & & & & & & \\
\hline$v(\mathrm{CCF})$ & 232 & & & & & & \\
\hline
\end{tabular}


Table 3.Vibrational spectra of some fluorinated benzene

\begin{tabular}{|c|c|c|c|c|c|c|c|}
\hline \multicolumn{2}{|c|}{ Monofluorobenzene } & \multicolumn{2}{|c|}{ Ortho-difluorobenzene } & \multicolumn{2}{|c|}{$\begin{array}{c}\text { Meta- } \\
\text { difluorobenzene }\end{array}$} & \multicolumn{2}{|c|}{$\begin{array}{c}\text { Para- } \\
\text { difluorobenzene }\end{array}$} \\
\hline $\begin{array}{c}\text { Form. } \\
\text { Fluctuatio } \\
\text { ns }\end{array}$ & v. $\mathrm{sm}^{-1}$ & $\begin{array}{c}\text { Form. } \\
\text { fluctuations }\end{array}$ & v. $\mathrm{sm}^{-1}$ & $\begin{array}{c}\text { Form. } \\
\text { fluctuatio } \\
\text { ns }\end{array}$ & v. $\mathrm{sm}^{-1}$ & $\begin{array}{l}\text { Form. } \\
\text { Fluctuat } \\
\text { ions }\end{array}$ & v. $\mathrm{sm}^{-1}$ \\
\hline $\mathrm{q}(\mathrm{CH})$ & 3100 & $q(\mathrm{CH})$ & 3081 & $\mathrm{q}(\mathrm{CH})$ & 3086 & $\mathrm{q}(\mathrm{CH})$ & 3074 \\
\hline $\mathrm{q}(\mathrm{CH})$ & 3087 & $q(\mathrm{CH})$ & 3060 & $\mathrm{Q}(\mathrm{C}-\mathrm{C})$ & 1613 & $\mathrm{q}(\mathrm{CH})$ & 3065 \\
\hline $\mathrm{q}(\mathrm{CH})$ & 3067 & $\mathrm{Q}(\mathrm{C}-\mathrm{C})$ & 1619 & $\mathrm{Q}(\mathrm{C}-\mathrm{C})$ & 1605 & $\mathrm{Q}(\mathrm{C}-\mathrm{C})$ & 1511 \\
\hline $\mathrm{q}(\mathrm{CH})$ & 3053 & $\mathrm{Q}(\mathrm{C}-\mathrm{C})$ & 1610 & $\mathrm{Q}(\mathrm{C}-\mathrm{C})$ & 1490 & $\mathrm{Q}(\mathrm{C}-\mathrm{C})$ & 1437 \\
\hline $\mathrm{q}(\mathrm{CH})$ & 3040 & $\mathrm{Q}(\mathrm{C}-\mathrm{C})$ & 1511 & $\mathrm{Q}(\mathrm{C}-\mathrm{C})$ & 1449 & $\beta(\mathrm{CCH})$ & 1285 \\
\hline $\mathrm{Q}(\mathrm{C}-\mathrm{C})$ & 1597 & $\mathrm{Q}(\mathrm{C}-\mathrm{C})$ & 1472 & $\mathrm{Q}(\mathrm{C}-\mathrm{C})$ & 1337 & $\beta(\mathrm{CCH})$ & 1225 \\
\hline $\mathrm{Q}(\mathrm{C}-\mathrm{C})$ & 1499 & $\mathrm{Q}(\mathrm{C}-\mathrm{C})$ & 1313 & $\beta(\mathrm{CCH})$ & 1277 & $\beta(\mathrm{CCH})$ & 1085 \\
\hline $\mathrm{Q}(\mathrm{C}-\mathrm{C})$ & 1460 & $\beta(\mathrm{CCH})$ & 1292 & $\beta(\mathrm{CCH})$ & 1259 & $\beta(\mathrm{CCH})$ & 1012 \\
\hline $\mathrm{Q}(\mathrm{C}-\mathrm{C})$ & 1326 & $\beta(\mathrm{CCH})$ & 1272 & $\beta(\mathrm{CCH})$ & 1157 & $\mathrm{P}$ & 943 \\
\hline $\mathrm{Q}(\mathrm{C}-\mathrm{F})$ & 1220 & $\beta(\mathrm{CCH})$ & 1206 & $\beta(\mathrm{CCH})$ & 1120 & $\mathrm{P}$ & 837 \\
\hline $\mathrm{Q}(\mathrm{C}-\mathrm{C})$ & 1156 & $\beta(\mathrm{CCH})$ & 1152 & $\beta(\mathrm{CCH})$ & 1068 & $\gamma(\mathrm{CCF})$ & 737 \\
\hline$\beta(\mathrm{CCH})$ & 1066 & $\beta(\mathrm{CCH})$ & 1101 & $\gamma(\mathrm{CCF})$ & 954 & $\mathrm{X}$ & 506 \\
\hline $\mathrm{Q}(\mathrm{C}-\mathrm{C})$ & 1020 & $\beta(\mathrm{CCH})$ & 1024 & $\rho$ & 852 & $\mathrm{X}$ & 405 \\
\hline$\beta(\mathrm{CCH})$ & 1008 & $P$ & 982 & $\rho$ & 771 & $\gamma(\mathrm{CCF})$ & 350 \\
\hline $\mathrm{P}$ & 994 & $\mathrm{P}$ & 930 & $\gamma(\mathrm{CCF})$ & 734 & $\rho(\mathrm{CF})$ & 163 \\
\hline $\mathrm{P}$ & 896 & $\gamma(\mathrm{CCF})$ & 856 & $\chi$ & 674 & & \\
\hline$\beta(\mathrm{CCH})$ & 806 & $\mathrm{P}$ & 840 & $\gamma(\mathrm{CCF})$ & 524 & & \\
\hline $\mathrm{P}$ & 752 & $\gamma(\mathrm{CCF})$ & 762 & $\gamma(\mathrm{CCC})$ & 514 & & \\
\hline $\mathrm{P}$ & 685 & $\mathrm{P}$ & 749 & $\gamma(\mathrm{CCF})$ & 478 & & \\
\hline$\gamma(\mathrm{CCC})$ & 615 & $P$ & 701 & $\chi$ & 458 & & \\
\hline$\gamma(\mathrm{CCC})$ & 520 & $\mathrm{P}$ & 588 & & & & \\
\hline $\mathrm{X}$ & 501 & $\gamma(\mathrm{CCF})$ & 566 & & & & \\
\hline$\gamma(\mathrm{CCF})$ & 405 & $\gamma(\mathrm{CCF})$ & 546 & & & & \\
\hline & & $\mathrm{X}$ & 451 & & & & \\
\hline & & $\gamma(\mathrm{CCF})$ & 441 & & & & \\
\hline
\end{tabular}

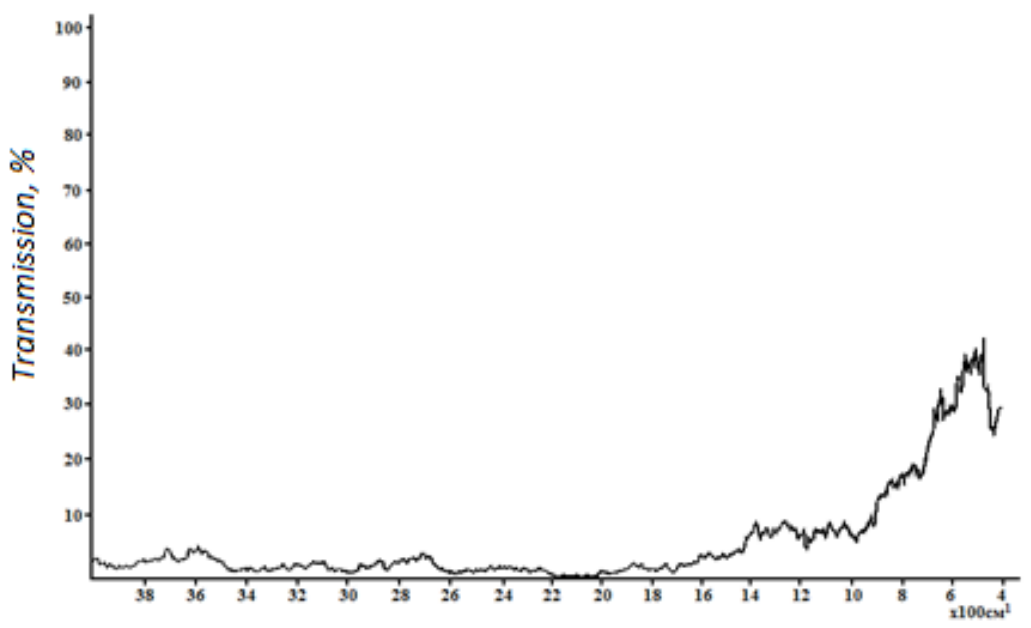

Fig. 2. IRS PVDF soot (0.04) 


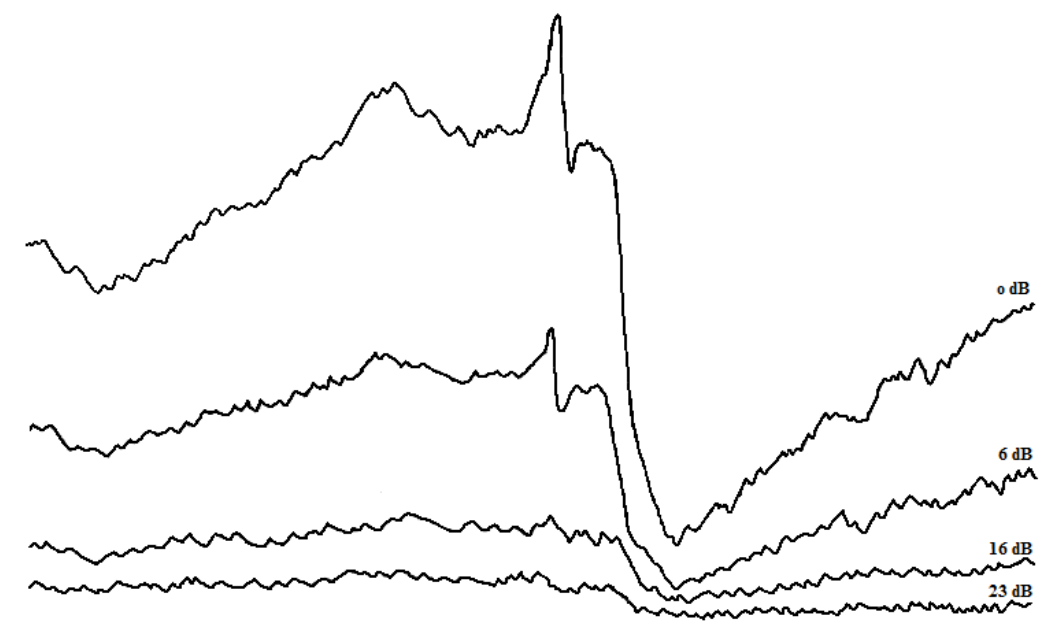

Fig. 3. EPR PVDF soot (0.04)

If we pay attention to the transmittance of soot (Figure 1) and composite (Figure 2) in the range of $4000-1000 \mathrm{~cm}^{-1}$. it is easy to notice that the composite is more strongly absorbing than soot (in our experiments. the amount of soot in the composite and $\mathrm{KBr}$ is almost the same)

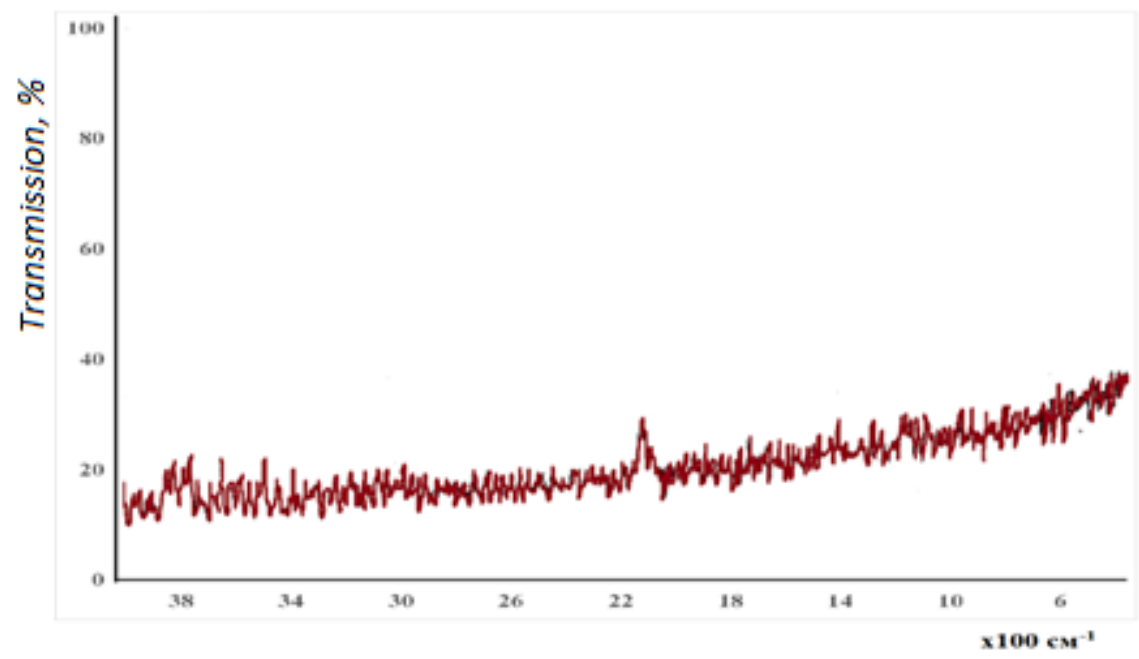

Fig.1. IR spectrum of soot

According to [3. 5], this may be due to the formation of such compounds as $\mathrm{CH}_{3} \mathrm{OH}$, $\mathrm{CF}_{4}$, and $\mathrm{F}_{2} \mathrm{O}_{2}$ in the composite. It is such compounds that have the ability of continuous absorption in the entire IR range. At present, we have a great tendency to give preference to the possibility of formation of $\mathrm{F}_{2} \mathrm{O}_{2}$ bonds in the composite, and we do not exclude the location of this bond in any of the fluorobenzenes. The study of the paramagnetic characteristics of the composite will have to bring some clarity regarding the validity of the arguments advanced. A strikingly strong broadening of the EPR signal of the composite, as can be seen from Figure 3, leads its cooking process, as in [6]. The EPR line width DNRR $=7273$ far exceeds the signal width of soot in air DNRR $=223$. Composite in line width parameter exceeds all mentioned in table 4 and 5, nickel microwave ferrites and yttrium- 
aluminum ferrogranates, as well as many of those given in table 6 single-crystal garnet ferrites. The reasons for such a strong broadening in the case of this composite may be due to the presence of an indirect mechanism of interaction.

Table 4. Magnetic and electrical properties of nickel super high-frequency ferrites

\begin{tabular}{|l|l|l|l|l|l|l|}
\hline Mark & Composition & $\begin{array}{c}\text { Saturation } \\
\text { magnetization. } \\
\text { KA/m }\end{array}$ & $\begin{array}{c}\text { Curve } \\
\text { width } \\
\text { DMR. } \\
\text { KA/m }\end{array}$ & $\begin{array}{c}\text { The } \\
\text { dielectric } \\
\text { constant }\end{array}$ & $\begin{array}{c}\text { Dielectric } \\
\text { loss } \\
\text { tangent }\end{array}$ & $\begin{array}{c}\text { Apparent } \\
\text { density. } \\
\text { gr/sm }\end{array}$ \\
\hline 10 SCH12 & Ni. $\mathrm{Cr}$ & 87.5 & 18.0 & - & - & - \\
\hline 2 SCH 7 & Ni. Zn & 280.0 & 24.0 & 13.2 & 0.8 & 5.17 \\
\hline 1 SCH 4 & Ni. Zn & 378.0 & 13.5 & 13.2 & 0.8 & 5.15 \\
\hline SCH 1 & Ni. Zn & 382.0 & - & - & - & 5.00 \\
\hline
\end{tabular}

Table 5. Magnetic and electrical properties of yttrium-aluminum super high-frequency ferrogranates

\begin{tabular}{|l|c|c|c|c|c|c|}
\hline Mark & Composition & $\begin{array}{c}\text { Saturation } \\
\text { magnetization. } \\
\text { KA/m }\end{array}$ & $\begin{array}{c}\text { Curve } \\
\text { width } \\
\text { DMR. } \\
\text { KA/m }\end{array}$ & $\begin{array}{c}\text { The } \\
\text { dielectric } \\
\text { constant }\end{array}$ & $\begin{array}{c}\text { Dielectric } \\
\text { loss } \\
\text { tangent }\end{array}$ & $\begin{array}{c}\text { Apparent } \\
\text { density. } \\
\text { gr/sm }\end{array}$ \\
\hline 90 SCHV & YA1 & 16.7 & 2.0 & 13.7 & - & 4.93 \\
\hline 80 SCHV & YA1 & 25.5 & - & 13.8 & - & 4.94 \\
\hline 70 SCHV & YA1 & 31.8 & 2.4 & 13.9 & 2 & 4.98 \\
\hline 60 SCHV & YA1 & 38.2 & 4.0 & - & - & 5.01 \\
\hline 50 SCHV & YA1. CaV & 47.0 & 5.8 & 14.0 & 3 & 4.76 \\
\hline S0SCH5V & YA1 & 51.3 & 4.0 & - & - & 5.03 \\
\hline 40SCH2V & YA1 & 62.1 & - & 14.2 & - & 5.06 \\
\hline 30SCH9V & YA1 & 82.0 & 3.2 & 14.5 & 2 & - \\
\hline 30SCH3V & YA1 & 97.1 & 4.0 & 14.6 & - & 5.09 \\
\hline 20SCH6 & YA1 & 111.5 & - & 14.8 & - & 5.10 \\
\hline 10SCH6V & Y & 141.7 & 2.4 & 15.1 & - & 5.12 \\
\hline
\end{tabular}

Table 6. Magnetic properties of some garnet ferrite single crystals

\begin{tabular}{|c|c|c|c|c|c|c|}
\hline Monocrystal & Composition & $\begin{array}{c}\text { Saturation } \\
\text { magnetization. } \\
\kappa \mathrm{A} / \mathrm{m}\end{array}$ & $\begin{array}{l}\text { Curve } \\
\text { width } \\
\text { DMR. } \\
\text { кA/m } \\
\end{array}$ & $\begin{array}{l}\text { Anisotrop } \\
\text { y field. } \\
\text { кA/m }\end{array}$ & $\begin{array}{l}\text { Curie } \\
\text { Point }\end{array}$ & $\begin{array}{l}\text { X-ray density. } \\
\mathrm{gr} / \mathrm{sm}^{3}\end{array}$ \\
\hline $150 \mathrm{KG}$ & YSc & 148.0 & 48 & 2.00 & 513 & 5.13 \\
\hline 140KG 1 & YFe & 140.0 & 48 & 3.40 & 556 & 5.17 \\
\hline $120 \mathrm{KG}$ & YFeGa & 120.0 & 48 & 3.40 & 543 & 5.19 \\
\hline $65 \mathrm{KG}$ & GaV:Ge & 65.6 & 48 & 0.88 & 443 & 4.0 \\
\hline $50 \mathrm{KG}$ & $\mathrm{BiGaV}$ & 49.6 & 96 & 1.76 & 498 & 4.26 \\
\hline $35 \mathrm{KG}$ & BiGaV:In & 34.4 & 48 & 1.84 & 448 & 4.16 \\
\hline $25 \mathrm{KG}$ & BiGaV:InNb & 24.0 & 80 & 2.16 & 433 & 4.19 \\
\hline $15 \mathrm{KG}$ & BiGaV:InNb & 16.0 & 64 & 2.40 & 418 & 4.20 \\
\hline $12 \mathrm{KG}$ & BiGaV:InNb & 11.2 & 80 & - & 395 & 41.6 \\
\hline
\end{tabular}

We think so because, according to the data in Table 7, the second constant is ultrafine splitting (UFS) $\mathrm{A}_{0}=277 \mathrm{MHz}$, and it is between 150-400 MHz, i.e., the value of which, according to [7], divides and sets the boundary between the contributions of the direct and indirect exchange interaction of spins. 
Table 7. Dependence of the UFR constants and spin densities on the $\mathrm{s}$ and $\mathrm{p}$ orbitals C. F. O. and $\mathrm{H}$ on the soot content in PVDF

\begin{tabular}{|c|c|c|c|c|c|c|c|c|c|c|c|c|c|}
\hline $\mathrm{V}_{1}$ & $\mathrm{a}_{1}$ & $\mathrm{a}_{2}$ & $\mathrm{~A}_{01}$ & $\mathrm{~A}_{02}$ & \multicolumn{2}{|c|}{${ }^{13} \mathrm{C}$} & \multicolumn{2}{|c|}{${ }^{19} \mathrm{~F}$} & \multicolumn{3}{c|}{${ }^{17} \mathrm{O}$} & \multicolumn{3}{c|}{$\mathrm{H}$} \\
\cline { 2 - 13 } & Ers & Ers & $\mathrm{Mhz}$ & $\mathrm{Mhz}$ & $\mathrm{p}_{\mathrm{s}}$ & $\mathrm{p}_{\mathrm{p}}$ & $\mathrm{p}_{\mathrm{s}}$ & $\mathrm{p}_{\mathrm{p}}$ & $\mathrm{p}_{\mathrm{s}}$ & $\mathrm{p}_{\mathrm{p}}$ & $\mathrm{p}_{\mathrm{s}}$ & $\mathrm{p}_{\mathrm{p}}$ \\
\hline 0.01 & 580 & 350 & 1786 & 1078 & 0.574 & 11.87 & 0.037 & 0.711 & - & - & 0.759 & 0.386 \\
& & & & & & & & & & 7.48 & & \\
\hline 0.02 & - & - & - & - & - & - & - & - & - & - & - & - \\
\hline 0.03 & 300 & 165 & 924 & 508 & 0.297 & 5.6 & 0.019 & 0.335 & - & - & 0.357 & 0.199 \\
& & & & & & & & & & 3.55 & & \\
\hline 0.04 & 410 & 90 & 1263 & 277 & 0.406 & 3.05 & 0.026 & 0.183 & - & - & 0.195 & - \\
& & & & & & & & & 0.27 & 1.92 & & \\
\hline 0.08 & 200 & - & 613 & - & - & - & - & - & - & - & - & - \\
\hline 0.15 & 465 & - & 1425 & - & - & - & - & - & - & - & - & - \\
\hline 0.20 & 400 & - & 1226 & - & - & - & - & - & - & - & - & - \\
\hline 0.25 & 490 & - & 1502 & - & - & - & - & - & - & - & - & - \\
\hline 0.3 & 530 & - & 1625 & - & - & - & - & - & - & - & - & - \\
\hline 0.4 & - & - & - & - & - & - & - & - & - & - & - & - \\
\hline
\end{tabular}

However, at first, one should be convinced of the reality of the presence of UFR in the composite. So, according to table 8 and 9 , the variability of saturation parameters from the microwave field of the narrow component and the common EPR signal are approximately similar in nature, which can be used in favor of the existence of the UFR in the composite.

Table 8. Dependence of the saturation parameters of a large EPR signal on the microwave power for PVDF composites with soot in the amount of $\mathrm{V}_{1}=0.04$

\begin{tabular}{|c|c|c|c|c|c|}
\hline $\mathrm{W} . \mathrm{mVt}$ & $\frac{I_{\chi}}{I_{\mathrm{ot}}}$ & $\mathrm{Z}$ & $\mathrm{S}$ & $\sqrt{\frac{1-S}{S}}$ & $\frac{1}{4} \cdot H_{1}^{2} \cdot v^{2} \cdot T_{1} \cdot T_{2}$ \\
\hline 5 & $2.8 \cdot 10^{-3}$ & 0.411 & 0.17 & 2.21 & $5.7 \cdot 10^{1}$ \\
\hline 25 & $2.7 \cdot 10^{-3}$ & 0.397 & 0.157 & 2.31 & $2.87 \cdot 10^{2}$ \\
\hline 50 & $2.84 \cdot 10^{-3}$ & 0.417 & 0.174 & 2.17 & $5.7 \cdot 10^{2}$ \\
\hline 100 & $2.96 \cdot 10^{-3}$ & 0.435 & 0.189 & 2.07 & $1.14 \cdot 10^{3}$ \\
\hline 150 & $3.2 \cdot 10^{-3}$ & 0.47 & 0.22 & 1.88 & $1.72 \cdot 10^{3}$ \\
\hline 200 & $3.4 \cdot 10^{-3}$ & 0.499 & 0.25 & 1.73 & $2.29 \cdot 10^{3}$ \\
\hline
\end{tabular}

Table 9. Dependence of saturation parameters, narrow EPR signal on the microwave power for PVDF composites with soot in the amount of $\mathrm{V}_{1}=0.04$

\begin{tabular}{|c|c|c|c|c|c|c|}
\hline $\begin{array}{c}\mathrm{W} . \\
\mathrm{mVt}\end{array}$ & $\mathrm{Z}$ & $\mathrm{S}$ & $\sqrt{\frac{1-S}{S}}$ & $\mathrm{H}_{\mathrm{PP}}$ ers & $\begin{array}{c}\mathrm{H}_{\mathrm{PP}} \\
\mathrm{KA} / \mathrm{m}\end{array}$ & $\frac{1}{4} \cdot H_{1}^{2} \cdot v^{2} \cdot T_{1} \cdot T_{2}$ \\
\hline 5 & 0.36 & 0.129 & 2.59 & 28.9 & 2.1 & $2.4 \cdot 10^{2}$ \\
\hline 25 & 0.38 & 0.144 & 2.43 & - & - & $1.2 \cdot 10^{2}$ \\
\hline 50 & 0.44 & 0.193 & 2.04 & 38.7 & 3.08 & $2.4 \cdot 10^{3}$ \\
\hline 100 & 0.452 & 0.2 & 2.0 & - & - & $4.7 \cdot 10^{3}$ \\
\hline 150 & 0.444 & 0.197 & 2.01 & - & - & $7.1 \cdot 10^{3}$ \\
\hline 200 & 0.44 & 0.193 & 2.04 & 40.9 & 3.25 & $9.5 \cdot 10^{3}$ \\
\hline
\end{tabular}

The calculations made for the Zeeman energy $(\Delta \mathrm{W})$ and measures of the interaction energies between the electron and the nucleus $\left(\mathrm{hA}_{0}\right)$ (see Table 10) show that "second order" UFRs cannot occur in the composite. 
Table 10. Dependence of the main parameters of the UFR of the narrow component of the EPR signal of PVDF composites on the carbon black content

\begin{tabular}{|c|c|c|c|c|c|c|}
\hline $\mathrm{V}_{1}$ & $\mathrm{~g}$ & $\mathrm{~W} . \mathrm{eV}$ & $\mathrm{hA}_{0} \cdot \mathrm{eV}$ & $\mathrm{H}_{\mathrm{PP}} \mathrm{eV}$ & $\mathrm{T}_{1} \cdot \mathrm{sek}$ & $\mathrm{T}_{2} \cdot \mathrm{sek}$ \\
\hline 0.03 & 2.048 & $3.98 \cdot 10^{-5}$ & $3.64 \cdot 10^{-5}$ & 68 & $4.3 \cdot 10^{-3}$ & $2.2 \cdot 10^{-9}$ \\
\hline 0.04 & 2.03 & $3.92 \cdot 10^{-5}$ & $4.97 \cdot 10^{-5}$ & 26.9 & $2.1 \cdot 10^{-3}$ & $6.6 \cdot 10^{-9}$ \\
\hline
\end{tabular}

Therefore, the contribution to the total EPR signal of the composite only from the $\mathrm{CF}_{3}$ radical is doubtful. It seems to us unlikely that the UFR will originate from the methyl radical $\mathrm{CH}_{3}$ and the cation of the vacant center $\mathrm{F}_{2}$, since their cleavage parameters, $\mathrm{a}=887$ ers and 59 ers, respectively, do not coincide with those of the composite (Table 7). Radicals of the SF, SH, SO types cannot contribute to the EPR signal of the composite because of their short survivability [6.7].

Analyzes concerning the conditions of spin normalization on the s orbitals $\mathrm{C}, \mathrm{F}, \mathrm{O}$ (Table 7) show that UFR in the composite can occur either on fluorine or oxygen, but in no case on carbon. The presence of singlet oxygen in the composite seems possible since the weak band of the composite $1400 \mathrm{~cm}^{-1}$ can come precisely from such oxygen. On the other hand, according to [6-12], it is singlet oxygen that can be responsible for the abnormal absorption of the super high-frequency field by the composite (see Table 11).

Table 11.The effect of absorption of the super high frequency field by composites depending on the soot content in PVDF

\begin{tabular}{|c|c|c|c|c|c|c|c|c|c|}
\hline $\mathrm{V}_{1}$ & 0.01 & 0.02 & 0.03 & 0.04 & 0.08 & 0.15 & 0.2 & 0.3 & 0.4 \\
\hline Y Rel.ed. & 0 & 0 & 0 & 12 & 27 & 8 & 35 & 23 & 41 \\
\hline
\end{tabular}

But the presence of triplet oxygen in a composite is doubtful for two reasons:

1. In the vibrational spectra of the composite, there is no band $1580.19 \mathrm{~cm}^{-1}$, characteristic of triplet oxygen;

2. The immutability of the intensity of the EPR signal of the composite (see table 12) from the influence of illumination by visible light.

According to [7], in the event of the presence of triplet $\mathrm{O}_{2}$ in the composite, it would be practically impossible to slow its diffusion to other radicals.

Table 12. Dependence of the EPR signal intensity on the saturation of composites with visible light

\begin{tabular}{|c|c|c|c|c|c|c|}
\hline $\mathrm{V}_{1}$ & \multicolumn{3}{|c|}{ The effect of light on a large EPR signal } & \multicolumn{3}{c|}{$\begin{array}{c}\text { The effect of light on the narrow } \\
\text { component of the EPR signal }\end{array}$} \\
\cline { 2 - 7 } & $\begin{array}{c}\text { Before } \\
\text { lighting }\end{array}$ & $\begin{array}{c}\text { After } \\
\text { lighting in } \\
\text { tech. 2 } \\
\text { minutes }\end{array}$ & $\begin{array}{c}\text { After 5 } \\
\text { minutes } \\
\text { after off } \\
\text { lighting }\end{array}$ & $\begin{array}{c}\text { Before } \\
\text { lighting }\end{array}$ & $\begin{array}{c}\text { After } \\
\text { lighting in } \\
\text { tech. 2 } \\
\text { minutes }\end{array}$ & $\begin{array}{c}\text { After 5 } \\
\text { minutes } \\
\text { after off } \\
\text { lighting }\end{array}$ \\
\hline 0.01 & 279 & 279 & 279 & 14 & 14 & 14 \\
\hline 0.02 & 254 & 254 & 254 & 22 & 22 & 22 \\
\hline 0.03 & 221 & 221 & 221 & 15 & 15 & 15 \\
\hline 0.04 & 168 & 168 & 168 & 18 & 18 & 18 \\
\hline
\end{tabular}


Table 13. Dependence of the main paramagnetic parameters of a large PVDF signal on the amount of soot

\begin{tabular}{|c|c|c|c|c|c|c|c|}
\hline $\mathrm{V}_{1}$ & $\mathrm{G}$ & $\mathrm{N} . \operatorname{spin} / \mathrm{gr}$ & $\begin{array}{c}\mathrm{H}_{\mathrm{PP}}^{\mathrm{o}} \\
\text { ers }\end{array}$ & $\begin{array}{c}\mathrm{H}_{\mathrm{PP}}^{\mathrm{o}} \\
\mathrm{KA} / \mathrm{m}\end{array}$ & $\mathrm{T}_{1} \cdot$ sek & $\mathrm{T}_{2}$. sek & $\begin{array}{c}\left(\frac{h v}{h c}\right) \text { SHF. } \\
\mathrm{sm}^{-1}\end{array}$ \\
\hline 0.01 & 2.098 & $7.14 \cdot 10^{14}$ & 1050 & 83.5 & $4.6 \cdot 10^{-2}$ & $\begin{array}{c}11.2 \cdot 10^{-} \\
10\end{array}$ & 0.328 \\
\hline 0.02 & 2.004 & $1.64 \cdot 10^{15}$ & 380 & 30.2 & $2.1 \cdot 10^{-2}$ & $\begin{array}{c}3.78 \cdot 10^{-} \\
10\end{array}$ & 0.346 \\
\hline 0.03 & 2.059 & $2.6 \cdot 10^{15}$ & 660 & 52.5 & $2.1 \cdot 10^{-2}$ & $\begin{array}{c}1.57 \cdot 10^{-} \\
10\end{array}$ & 0.336 \\
\hline 0.04 & 2.077 & $1.3 \cdot 10^{15}$ & 724 & 57.6 & $4.5 \cdot 10^{-2}$ & $2.1 \cdot 10^{-10}$ & 0.333 \\
\hline 0.08 & 2.084 & & 320 & 25.4 & & & 0.334 \\
\hline 0.15 & 2.061 & $2.36 \cdot 10^{14}$ & 700 & 55.7 & $3 \cdot 10^{-2}$ & $8.8 \cdot 10^{-11}$ & 0.324 \\
\hline 0.20 & 2.070 & & 510 & 40.6 & & & 0.322 \\
\hline 0.25 & 2.071 & & 630 & 50.1 & & & 0.322 \\
\hline 0.3 & 2.082 & & 640 & 50.9 & & & 0.320 \\
\hline 0.4 & 2.14 & & 80 & 6.36 & & & 0.333 \\
\hline
\end{tabular}

One possible compound with a triplet state responsible for the UFR in the composite is, again, three fluoroethylene. The independence of the EPR signal from the influence of light:

Firstly, the fact of the fulfillment of $\mathrm{h} v / \mathrm{hc}<\mathrm{D}=0.72 \mathrm{~cm}-1$ (see Table 13), which would lead to the observation of only some of the lines allowed by the selection rules;

Secondly, it could be interpreted in favor of this compound.

However, such a strong broadening of the total EPR signal of the composite due to the indirect exchange interaction with the radical of this compound is not possible [6-12]. Another and more plausible, in our opinion, the compound responsible for the strong broadening of the EPR signal in the composite may be the perfluoro-p-benzo-semiquinone radical because it is singlet oxygen with an ordinary $\mathrm{C}=\mathrm{O}$ bond in it that can provide the presence of a non-binding molecular orbital [13-15]. The localization of electrons that populate this non-binding molecular orbital once [6.13.15] due to the indirect mechanism of interaction through delocalized $\pi$-electrons can lead to super-exchange interaction and, as a result, to a strong broadening of the EPR signal of the composite, research on the unique properties of composite materials has received a lot of attention, including research on magnetic and paramagnetic properties [16-20].

\section{Conclusions}

Summarizing the above, it should be concluded that:

1. The IR spectrum of the composite is an overlay of signals from PVDF + DMSO + IFL + carbon black;

2. IFL in the composite can be of several types;

3. The multicomponent nature of the overall EPR signal of the composite can occur from the UFR on fluorine and oxygen with isotopes 19 and 17, respectively;

4. Among the possible reasons leading to a strongly inhomogeneous broadening of the EPR line of the composite, there may be an indirect mechanism of the exchange interaction between spins ;

5. The composite is promising as a magnetic material and a thermal receiver of infrared rays. 


\section{References}

1. Martin Badertscher. Philippe Bülhmann. Ernö Pretsch. Structure Determination of Organic Compounds: Tables of Spectral Data. Springer-Verlag Berlin Heidelberg 2009. DOI: $10.1007 / 978-3-540-93810-1$

2. Rabek Y. Experimental methods in polymer chemistry. Per. with eng. under the editorship of Korshova V.V. M. World. T.2. 1983. p. 473. (in Russian).

3. Gerhard Herzberg Electronic spectra and electronic-structure of polyatomic molecules. Moskva. Mir. 1969. p. 772 (in Russian).

4. Chernov V.M.. Krasnopolsky G.S. Correlation time spectrum in linear polymer melts and Doi-Edwards polymer dynamics model // Abstracts of AMPERE NMR School. Poznan/Wierzba. 22/06-01/07/2006. Poland. 2006. P. 40

5. Gureva S.A.. Marikhin V.A. Investigation of structural transformations of long-chain molecular crystals during phase transitions by IR-spectroscopy J. Phys. Conf. Ser. 2019. 1236. 012008

6. Umarov A.V.. Kamalova D.I.. Study of the characteristic features of the strongest broadening of the EPR signal in polystyrene-based polymer compositions Journal of Chemistry2020. V 5. Issue 1. 2020. p. 1-11.

7. Johne Wert. James Bolton. Electron spin resonance. Elementary theory and applications. McGraw-Hill Book Company New York. 1972. p. 550

8. Altshuler S.A.. Kozyrev B.M. Electronic paramagnetic resonance. M. Science. 1992.p. 672. (in Russian).

9. Poole C. Technique of EPR spectroscopy. World. 1980. p. 558. (in Russian).

10. Yu.A. Pentin. L.V. Vilkov. Physical methods of research in chemistry. - M .: Mir. 2006 .-- 683 p. (in Russian).

11. Abbas Hamrang. Devrim Balkose. polimer research and technology. New Jersey apple academic press. 2014. $160 \mathrm{p}$.

12. Umarov. A.. Kamalova. D.. Investigation of ultrafine expansion in Epr studies of a polymer composition based on polystyrene // AIP Conference Proceedings. 2020. 2308. 030019.

13. Roduner E.. Schlik S.. // Advanced ESR methods in polymer research. Wiley Interscience. Hoboken. NJ. 2006. p. 197-228

14. Bartenev G.M. . Frenkel S.Ya.. Fizika polimerov. Leningrad. Kximiya. 1990. p. 432

15. Kinoshita Minoru // Solid state Phys. -1983. V. 24. N 8. p. 623-630.

16. Ziyamukhamedova U.A.. Bakirov L.Y.. Rakhmatov E.A.. Bektemirov B.Sh. Structure and properties of heterocomposite polymeric materials and coatings from them obtained by heliotechnological method / International Journal of Recent Technology and Engineering (IJRTE) ISSN: 2277-3878. Volume-8. Issue-3S. October 2019. P.399-402.

17. Parveen Saini (ed.) Fundamentals of Conjugated Polymer Blends. Copolymers and Composites. (3-118) 2015 Scrivener Publishing LLC

18. M. R. Lee. R. D. Eckert. K. Forberich. G. Dennler. C. J. Brabec. R. A. Gaudiana. Solar Power Wires Based on Organic Photovoltaic Materials. Science 2009. 324. 232235.

19. M. Krueger. M. Eck. Y. Zhou. F.-S. Riehle. Semiconducting Nanocrystal/ Conjugated Polymer Composites for Applications in Hybrid Polymer Solar Cells. In Semiconducting Polymer Composites; X. Yang. Ed.; Wiley-VCH Verlag GmbH \& Co. KGaA: Weinheim. Germany. 2013; pp. 361-397.

20. W. Li. T. Qiu. L. Wang. S. Ren. J. Zhang. L. He. X. Li. Preparation and Electromagnetic Properties of Core/Shell Polystyrene@Polypyrrole@Nickel Composite Microspheres. ACS Appl. Mater. Interfaces 2013. 5. 883-891. 